DOI: $10.17148 / I A R J S E T .2021 .8945$

\title{
A STUDY ON CONSUMER PERCEPTION ON GOOGLE SEARCH ENGINE AS AN ONLINE PLATFORM
}

\author{
Dr.J.MarySaranya ${ }^{1}$, Prof.B.Preethi ${ }^{2}$, Prof.D.Prashanth ${ }^{3}$ \\ ${ }^{1,2.3}$ Assistant Professor, Management Science, Sri Krishna Arts and Science College, Coimbatore
}

\begin{abstract}
Search engine optimization (SEO), as a multi-million dollar business of search engine marketing, has hardly ever been studied from the consumers' perspective. This study aims to be the first step of researching consumers' reaction to SEO as a marketing practice and its potential impact on online search behaviours. To know the consumer perception and Preference about Google search engine as an online platform. To analyze the impact of customer satisfaction on the long-term stability of the business. This topic is about analyzing the satisfaction of the consumers towards the services provided by Google. It has come through to give a clear cut idea of the evaluations of search engines and the websites directed. Its main aim is to find out the usage and pattern of Google, and also the general attitude of the consumers. Most of the participants' online search behaviors remain unmoved except for the number of diverse searches conducted. Theoreticaland practical implications are discussed.
\end{abstract}

Keywords: Search Engine, Consumers, Online platform, Marketing

\section{INTRODUCTION}

This research is based on the perception towards Google. Delivering quality service is of utmost important. They facilitate businesses and consumers to make the majority of the opportunities formed by the digital economy. Supported by the materialization of mobile devices and pervasive wireless connectivity, online platforms have altered how we live, cooperate and transact. Examples consist of search engines, online marketplaces, the joint or sharing economy, and social networks. "A number of online platforms have evolved to suit playerscompeting in various sectors of the economy and the technique they use their market power.

Need for the study

The study is to recognize the consumer perception of the Google search engine as an online platform for information acquisition tools.

\section{Objectives of the study}

- $\quad$ To study the customer value analysis which includes identifying the major attributes that customer's value in an online platform, assessing the quality of the different attributes.

- $\quad$ To shed light on different aspects that Google must follow in order to increase its market share and for being on a continuous growth stream.

- $\quad$ To know the consumer perception and Preference about varieties of services offered by Google.

- To become aware of the customer expectations from Google.

- $\quad$ To analyze the impact of customer satisfaction on the long-term profitability of the business.

Scope of the study

The scope of the study is covering internal and the external influence of the Organization to fine-tune the areas and the main reason that its technologies fitted with the company's existing capabilities-Widely which in turn gave the study a wide and large scope for analysis.

\section{Limitations of the study}

- $\quad$ The respondent's individual bias may be a different factor, which is uncontrollable.

- The study does not signify classes of managerial professionals not interviewed, such as individuals from educational institutions, health-related industries, law enforcement, or global businesses. 


\section{International Advanced Research Journal in Science, Engineering and Technology}

Vol. 8, Issue 9, September 2021

\section{DOI: $10.17148 / I A R J S E T .2021 .8945$}

\section{REVIEW OF LITERATURE}

David M. Szymanski and Richard T. Hise (2000) observed that e-retailers promise their customers that online experiences will be satisfying ones, understanding what creates a satisfying customer experience becomes crucial. Even though this understanding appears crucial, no studies have examined the factors that make consumers satisfied with their e-retailing experiences.

Goldsmith and Bridges (2000) found that consumers who felt that it was easy to buy over the web were more likely to buy, implying that confidence leads to greater purchase likelihood. A positive relationship between Internet experience/confidence and amount of shopping is thus found in his study.

\section{RESEARCH METHODOLOGY}

Haphazard execution of the study will end up itself in chaotic results, so to evade such happenings; the scholar is also required to plan well before he can start his work. The researcher is required to prepare a system operating procedure of action which is known as research design.

It ensures that

(1) the study will be germane to the problem and

(2) the study will employ economical procedures

\section{DESCRIPTIVE RESEARCH DESIGN}

The descriptive research is secondhand for this study. The main objective of consuming descriptive research is to pronounce the state of affairs as it exists at present. It mainly involves surveys and fact verdict inquiries of different classes.

\section{Statistical Tools and Techniques}

The collected data were edited and then consolidated by using simple statistical tools. The simple statistical tools are employed for the analyses of data are,

- Percentage analysis

○ Chi-square test

Weighted average method

\section{DATA ANALYSIS}

Table: 1

Age group of the Respondents

\begin{tabular}{|l|l|l|l|}
\hline S.No & Age Group & Frequency & Percentage \\
\hline 1 & Below 25 years & 198 & 19.8 \\
\hline 2 & $26-35$ years & 271 & 27.5 \\
\hline 3 & $36-45$ years & 333 & 33.8 \\
\hline 4 & $46-55$ years & 102 & 10.4 \\
\hline 5 & Above 55 years & 96 & 9.8 \\
\hline & Total & 1000 & 100 \\
\hline
\end{tabular}

\section{Inference}

The table portrays the distribution of the respondents based on their age group. Among the respondents 33.8 per cent opined that they belongs to the age group of $36-45$ years. This is followed by 27.5 per cent of the respondents who are between 26 - 35 years. Among the remaining respondents 19.8 per cent are below 25 years, 10.4 per cent between 46 55 years and the remaining 9.8 per cent are above 55 years. 
International Advanced Research Journal in Science, Engineering and Technology

Vol. 8, Issue 9, September 2021

DOI: $10.17148 / I A R J S E T .2021 .8945$

Age group of the Respondents

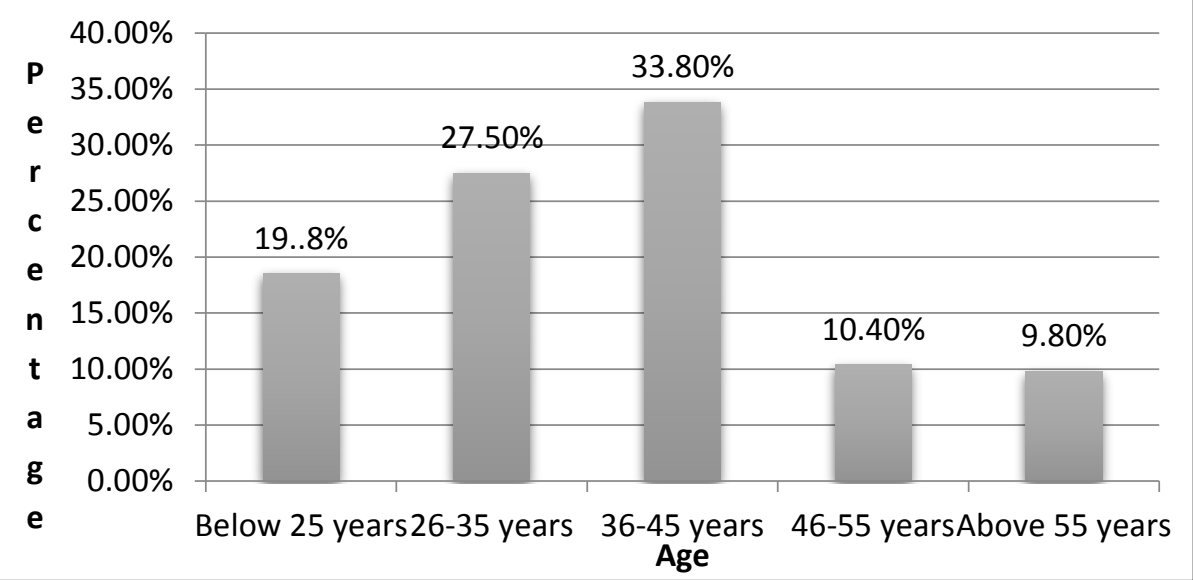

Frequently used products

\begin{tabular}{|l|l|l|l|}
\hline S.No & Particulars & Frequency & Percentage \\
\hline 1 & Google scholar & 184 & 18.4 \\
\hline 2 & Gmail & 348 & 34.8 \\
\hline 3 & Google+ & 174 & 17.4 \\
\hline 4 & YouTube & 294 & 29.4 \\
\hline & Total & 1000 & 100 \\
\hline
\end{tabular}

\section{Inference}

Majority 34 per cent of the respondents state that they hold Gmail. Among the remaining respondents 29.4 per cent state that they hold You Tube and the least 17.4 per cent state that they have google+.

Frequently used products

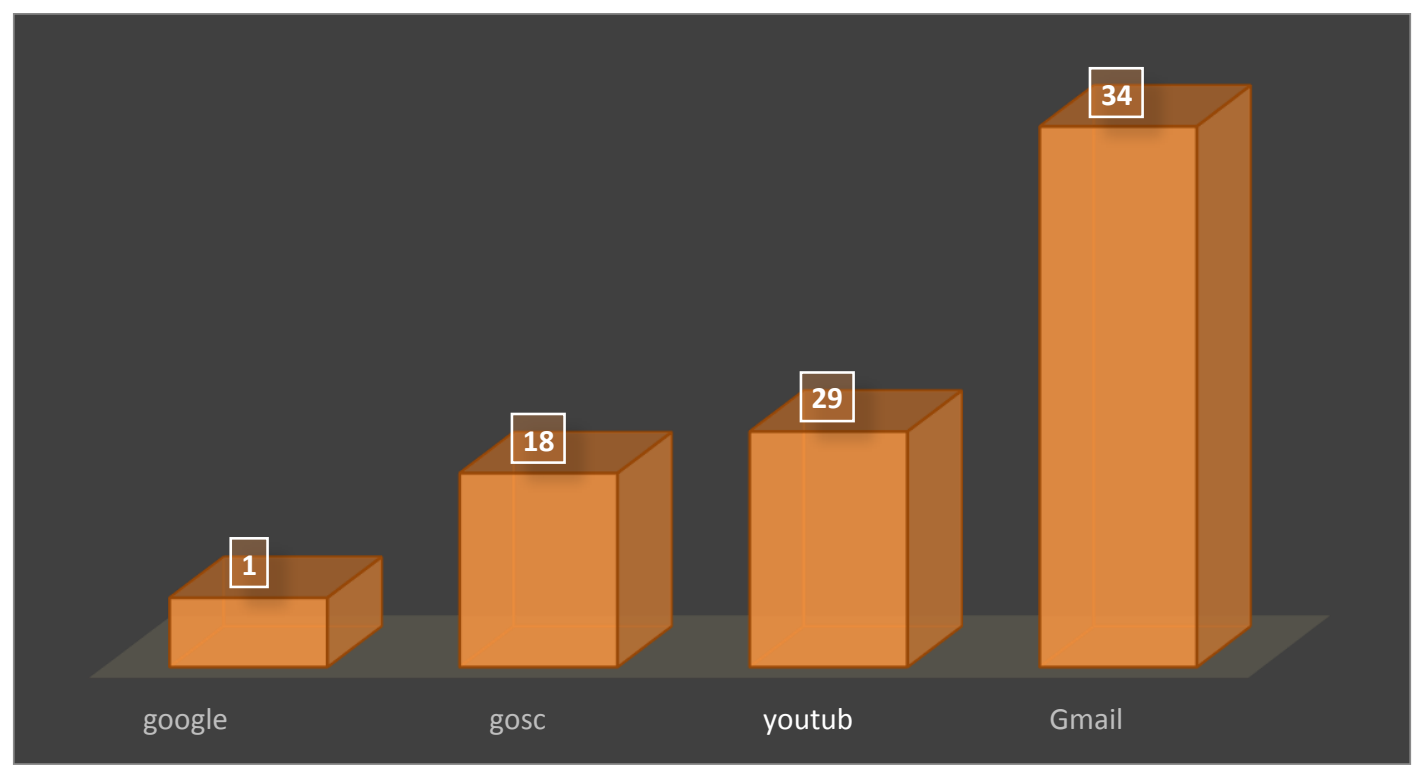




\section{International Advanced Research Journal in Science, Engineering and Technology}

Vol. 8, Issue 9, September 2021

DOI: 10.17148/IARJSET.2021.8945

\section{CHI-SQUARE TEST}

Null hypothesis $\left(\mathbf{H}_{0}\right)$ : There is no association between the age of the respondents andfrequently used products. Alternate hypothesis $\left(\mathbf{H}_{1}\right)$ : There is an association between the age of therespondents and frequently used products of Google.

\begin{tabular}{|l|l|l|l|l|l|l|}
\hline \multicolumn{7}{|c|}{ Age of the respondent * frequently used products } \\
\hline Count & & \multicolumn{3}{|c|}{} & & \\
\hline & & Frequently used products of Google & Total \\
\hline & & $\begin{array}{l}\text { Google } \\
\text { scholar }\end{array}$ & Gmail & Google+ & YouTube & \\
\hline $\begin{array}{c}\text { Age of } \\
\text { the } \\
\text { respondent }\end{array}$ & Below 15years & 70 & 100 & 50 & 20 & 240 \\
\hline & & & & & & \\
\hline & $15-30$ years & 70 & 150 & 150 & 20 & 390 \\
\hline Total & $30-45$ years & 70 & 80 & 70 & 30 & 250 \\
\hline
\end{tabular}

\begin{tabular}{|l|l|l|l|}
\hline \multicolumn{5}{|c|}{ Chi-Square Tests } \\
\hline & Value & Df & Asymp. Sig. (2-sided) \\
\hline Pearson Chi-Square & 100.92217 & 9 & 0.2810815720 \\
\hline Likelihood Ratio & 90.384445 & 9 & 0.4025694930 \\
\hline Linear-by-Linear Association & 20.091239 & 1 & 0.1481458730 \\
\hline N of Valid Cases & 1000 & & \\
\hline
\end{tabular}

\section{Interpretation}

The calculated value, 0.281 is less than 0.05 ; hence null hypothesis is accepted there issignificant relationship between the age of the respondents and frequently used productsof Google.

\section{Inference}

The Test Has Proven That There Is Significant Relationship between the Age of the Respondents and frequently used products.

\section{Findings}

- $\quad$ Majority $34 \%$ of the age respondent is in between $36-45$ percent.

- $\quad$ Majority 34\% of the respondents frequently use GMail.

- $\quad$ Majority $44 \%$ of the respondents says Google maps are mildly important.

\section{Suggestions}

- $\quad$ Make Google maps more users friendly.

- $\quad$ Enhance the quality of performance skill set of Google+ in better terms of other socialnetworking competitors.

- $\quad$ Include more promotional strategies and marketing development while retainingbrand equity.

- $\quad$ Bridge the language barrier gap by reaching out to remote locations while adapting the software to the respective languages.

\section{CONCLUSION}

Consumer behaviour is frequently studied because firm decisions are considerably affected by their behaviour or predictable actions. It can be concluded that Google strategies have been successful and there is flexibility in the strategies, as they can be changed with the changes in the market conditions as well as the targets. Google was attributed to the high quality of consistency and reliability. For instance, any location in the world can be viewed in an angle using the Google Maps and hence Google has altered our lifestyleof existence. The objectives of promotion are to introduce a new product, stimulate demand, change the short-term behaviour of the customers, and encourage repeat or greater usage by current customers of Google. It has created an ambience of utmost possibility of information around the world in order to reach the target market. 


\section{International Advanced Research Journal in Science, Engineering and Technology}

Vol. 8, Issue 9, September 2021

DOI: 10.17148/IARJSET.2021.8945

REFERENCES

- $\quad$ Kim, C., Park, S., Kwon, K \& Chang, W., 2012. How to Select Search Keywords for Online Advertising depending on Consumer Involvement: An Empirical Investigation. Expert Systems with Applications. Vol. 39 Issue: 1 pp. 594-610.

- $\quad$ Sharma, D., Gupta, A., Mateen, A. \& Pratap, S., 2018 Making sense of the changing face of Google's search engine results page: an advertiser's perspective. Journal of Information, Communication and Ethics in Society, Vol. 16 Issue: 1, pp.90-107

- $\quad$ Varnali, K., Yilmaz, C \& Toker, A., 2012. Predictors of attitudinal and behavioral outcomes in mobile advertising: A field experiment. Electronic Commerce Research and Applications.Vol.11Issue:6,pp.570-581

- Suraj S. Bhoite; Swapnali K. Londhe. "Aspect Based Online Sentiment Analysis Product Review and Feature Using Machine Learning". International Research Journal on Advanced Science Hub, 3, Special Issue 7S, 2021, 54-59.

\section{WEBSITES}

- https://www.google.co.in/?gfe_rd=cr\&dcr=0\&ei=3ia0WqTADKawX8jch

- https://en.wikipedia.org/wiki/Google

- $\quad$ https://www.youtube.com/user/Google

- https://www.google.com/tools/feedback/intl/en/

- https://conservancy.umn.edu/handle/11299/147494 